\title{
Unit Stroke di Rumah Sakit: Arti Penting dan Model Pelayanan
}

\section{Stroke Unit at a Hospital: The Importance and Service Model}

\author{
Ni Putu $E^{1}$, Agnes Widayu $E^{1}$, Dolly Irbantoro² \\ ${ }^{1}$ Program Studi Magister Manajemen Rumah Sakit Fakultas Kedokteran Universitas Brawijaya Malang \\ ${ }^{2}$ Rumah Sakit Baptis Batu
}

\begin{abstract}
ABSTRAK
Pentingnya pelayanan rehabilitasi medik dan tingginya kasus stroke mendorong kajian pengembangan unit stroke di rumah sakit. Tujuan studi ini adalah mengidentifikasi arti penting unit stroke dan model pelayanannya di rumah sakit. Studi ini menggunakan pendekatan deskriptif eksploratif untuk menggali pendapat stakeholder internal tentang arti penting dan alur model pelayanan unit stroke. Teknik pengumpulan data dengan wawancara tidak terstruktur pada semua komponen yang terlibat dalam pelaksanaan pelayanan di unit stroke meliputi wakil direktur pelayanan, dokter neurologi, kepala perawat intensive care unit (ICU), perawat mahir stroke, kepala perawat instalasi gawat darurat (IGD), dan dokter rehabilitasi medik RS Baptis Batu. Wawancara dilakukan selama satu minggu dari tanggal 21-25 September 2015 untuk menggali pendapat stakeholder internal mengenai rencana pengembangan unit stroke, alur pelayanannya, sumber daya yang diperlukan, dan hal lain yang terkait dengan pengembangan unit stroke di RS Baptis Batu. Berdasarkan hasil wawancara didapatkan bahwa semua staf yang terkait siap untuk mendukung rencana pengembangan unit stroke di RS Baptis Batu. Unit stroke merupakan unit pelayanan komprehensif pasien stroke yang dilakukan oleh tim multidisipliner serta kombinasi terapi untuk perawatan akut dan rehabilitasi dini. Unit stroke tersebut melayani pasien stroke fase akut. Setelah pasien melewati fase akut maka pasien stroke akan dipindahkan ke ruang perawatan biasa dan dipersiapkan juga perawatan khusus pasien stroke untuk perencanaan saat pasien pulang (discharge planning). Perlu dilakukan studi kelayakan terkait dengan manajemen, fasilitas, sumber daya manusia (perawat dan tim multidisipliner), serta pembiayaan unit stroke di RS Baptis Batu.
\end{abstract}

Kata Kunci: Alur pelayanan, tim multidisipliner, unit stroke

\begin{abstract}
The importance of medical rehabilitation services and the high incidence of stroke encourage the study of stroke unit development in hospitals. The aim of this study is to identify the importance of stroke unit and model of stroke services at the hospital. This study used an exploratory descriptive approach to gather opinion from the internal stakeholders about the importance and the flow of stroke unit care model. Data collection techniques were unstructured interviews conducted during a week of 21-25 September 2015 on all the components involved in the stroke unit such as deputy director, neurologist, head nurse of the intensive care unit (ICU), advanced stroke nurse, head nurse of emergency room (ER), and medical rehabilitation doctor. Based on the interview results, all staff are ready to support the development of stroke unit at Baptis Hospital Batu. The stroke unit is a unit providing comprehensive services for stroke patients conducted by a multidisciplinary team as well as a combination of therapy for the treatment of acute and early rehabilitation. When the patient has passed the acute phase, they will be transferred to a regular care room and prepared for a special care plan before discharged (discharge planning). Therefore, Baptis Hospital Batu needs to do a feasibility study related to the management, facilities, human resources (nurse and multidisciplinary team), as well as the financing of the stroke unit.
\end{abstract}

Keywords: Multidisciplinary team, stroke unit, the flow of services

Korespondensi: Ni Putu E. Program Studi Magister Manajemen Rumah Sakit Fakultas Kedokteran Universitas Brawijaya Malang, Jl. Veteran Malang Jawa Timur Tel. (0341) 568989Email: ekayaniputu86@gmail.com 


\section{PENDAHULUAN}

Data kinerja pelayanan di Instalasi Gawat Darurat (IGD) dan rawat jalan RS Baptis Batu menunjukkan beberapa indikator yang belum tercapai. Hal ini berpengaruh pada angka kunjungan pasien yang mengalami penurunan dari Tahun 2013 hingga 2014 sebesar 13\% (Tabel 1). Penurunan angka kunjungan rawat jalan dan IGD perlu dianalisis untuk menggali faktor yang mempengaruhi dari internal dan eksternal organisasi rumah sakit. Faktor internal yang dapat mempengaruhi adalah mutu pelayanan di RS Baptis Batu, mulai dari pelayanan IGD, rawat jalan, laboratorium, radiologi, rekam medis dan farmasi. Pada aspek eksternal penurunan kunjungan tersebut harus dibandingkan dengan pemetaan pasar yang ingin dijangkau oleh pihak rumah sakit, yaitu segi pemasaran RS Baptis Batu.

Tabel 1. Data kunjungan pasien di RS Baptis Batu tahun 2013Juni 2015

\begin{tabular}{ccc}
\hline Tahun & Kunjungan rawat jalan & Kunjungan IGD \\
\hline 2013 & 35.371 & 6.195 \\
2014 & 30.807 & 5.576 \\
Jan-Juni & & \\
2015 & 19.698 & 3.299 \\
\hline
\end{tabular}

Sumber: Laporan Tahunan RS Baptis Batu Tahun 2013-Juni 2015

Salah satu layanan unggulan di RS Baptis Batu adalah rehabilitasi medik. Layanan rehabilitasi medik adalah salah satu upaya kesehatan guna memulihkan fungsifungsi tubuh kembali seperti semula sehingga seseorang dapat hidup produktif kembali (1). Unit rehabilitasi medik RS Baptis Batu saat ini mulai menjadi unit yang berperan penting dalam pelayanan dan memiliki pasar yang semakin bertambah. Hal tersebut ditandai dengan peningkatan angka kunjungan pasien di unit rehabilitasi medik dari tahun ke tahun. Unit rehabilitasi medik RS Baptis Batu mempunyai pelayanan yang lebih komprehensif yang mempunyai tujuan untuk meminimalisir kecacatan, serta meningkatkan kualitas hidup dengan berbagai penanganan, seperti terapi okupasi, terapi wicara, alat bantu ortetik prostetik, termasuk juga fisioterapi(2).

Tabel 2 menunjukkan kunjungan pasien rehabilitasi medik tahun 2013 hingga tahun 2014 meningkat sebesar 1\%. Persentase jumlah kunjungan pasien rehabilitasi medik dibandingkan total kunjungan rawat jalan di RS Baptis Batu pada tahun 2014 sebesar 34\%. Persentase yang sama juga dicapai pada Januari-Juni 2015.

Kunjungan pasien paling banyak di rehabilitasi medik adalah pasien fisioterapi yang memiliki persentase sebesar 7,7\% pada tahun 2013 dan 0,7\% di tahun 2014 .

Tabel 2. Jumlah pasien rehabilitasi medik RS Baptis Batu tahun 2013-Juni 2015

\begin{tabular}{lrrr}
\hline Indikator & Tahun 2013 & Tahun 2014 & Jan-Juni 2015 \\
\hline Fisioterapi & 9.537 & 10.404 & 6.679 \\
Terapi okupasi & 549 & 67 & 0 \\
Terapi wicara & 302 & 0 & 0 \\
Jumlah & 10.388 & 10.479 & 6.679 \\
\hline \multicolumn{2}{l}{ Sumber: Laporan Tahunan RS Baptis Batu Tahun 2013-Juni 2015 }
\end{tabular}

Berdasarkan laporan tahunan RS Baptis Batu tahun 2014Juni 2015, kasus yang banyak ditangani di unit rehabilitasi medik RS Baptis Batu adalah kasus stroke. Tabel 3 memperlihatkan data pasien stroke yang menjalani perawatan di rehabilitasi medik. Kasus stroke di rehabilitasi medik memiliki persentase sebesar $14 \%$ dari total kunjungan pasien rehabilitasi medik tahun 2014 dan 11\% pada Januari hingga Juni 2015.

Tabel 3. Jumlah pasien stroke yang mendapat pelayanan di Rehabilitasi Medik RS Baptis Batu tahun 2014 dan Januari-Juni 2015

\begin{tabular}{lrccc}
\hline \multirow{2}{*}{ Bulan } & \multicolumn{2}{c}{ Tahun 2014 } & \multicolumn{2}{c}{ Jan-Juni Tahun 2015 } \\
\cline { 2 - 5 } & Rawat Jalan & Rawat Inap & Rawat Jalan & Rawat Inap \\
\hline Januari & 81 & 77 & 108 & 20 \\
Februari & 86 & 76 & 124 & 38 \\
Maret & 87 & 45 & 106 & 19 \\
April & 72 & 29 & 88 & 28 \\
Mei & 62 & 15 & 100 & 23 \\
Juni & 68 & 60 & 76 & 30 \\
Juli & 108 & 30 & & \\
Agustus & 73 & 28 & & \\
September & 112 & 22 & & \\
Oktober & 104 & 12 & & \\
November & 107 & 28 & & \\
Desember & 114 & 12 & & \\
\hline Total & 1074 & 434 & 602 & \\
\hline
\end{tabular}

Sumber: Laporan tahunan RS Baptis Batu tahun 2014 dan Januari-Juni 2015

Tingginya kasus stroke perlu dikelola dengan baik karena stroke merupakan penyebab kematian kedua di dunia, sedangkan di Amerika Serikat, stroke merupakan penyebab kematian ketiga terbanyak setelah penyakit jantung dan kanker. Sekitar 6,4 juta penduduk Amerika menderita stroke. Sekitar 795.000 orang di Amerika Serikat mengalami stroke setiap tahunnya dan sekitar 610.000 mengalami serangan stroke yang pertama. Stroke juga merupakan penyebab 134.000 kematian pertahun (3). Stroke merupakan penyebab kematian utama di Indonesia. Prevalensinya meningkat dengan bertambahnya umur, tertinggi pada umur $\geq 75$ tahun, gejala pada perempuan dan laki-laki sama(4).

Rendahnya kesadaran akan faktor risiko stroke, kurang dikenalinya gejala stroke, belum optimalnya pelayanan stroke dan rendahnya ketaatan terhadap program terapi untuk pencegahan stroke berulang merupakan permasalahan yang muncul pada pelayanan stroke di Indonesia sehingga perlu pengembangan pelayanan yang komprehensif (5-7). Berdasarkan tingginya permasalahan kesehatan akibat stroke yang membutuhkan pelayanan rehabilitasi, RS Baptis Batu menetapkan perlunya pengembangan unit stroke komprehensif. Komprehensif yang dimaksud adalah pelayanan stroke pada pasien prahospital, IGD, unit stroke, pelayanan rehabilitasi medik hingga pasien pulang. Hal lain yang mendukung adanya pengembangan unit stroke komprehensif di RS Baptis Batu adalah adanya fasilitas yang memadai berupa peralatan canggih yang dimiliki RS Baptis Batu yaitu CT scan 8 slices yang merupakan satu-satunya di wilayah Batu serta tim tenaga medis yang kompeten di bidangnya.

Unit stroke komprehensif ini bertujuan untuk mencegah kecacatan dan kematian lebih banyak pada penderita stroke serta menjadi daya ungkit penggunaan pelayanan 
rehabilitasitasi medik. Rencana pengembangan unit stroke komprehensif di RS Baptis Batu membuat peran unit rehabilitasi medik menjadi sangat penting dalam mendukung unit stroke tersebut. Pengembangan unit stroke komprehensif yang ditunjang oleh staf dan fasilitas yang lengkap akan memberikan daya ungkit peningkatan kunjungan di unit rehabilitasi medik sebagai layanan unggulan di RS Baptis Batu. Tujuan studi ini adalah untuk mengidentifikasi pentingnya dan alur model pelayanan unit stroke di RS Baptis Batu. Studi ini diharapkan dapat menjadi masukan bagi RS Baptis Batu dalam rangka pengembangan unit stroke komprehensif.

\section{METODE}

Studi ini menggunakan pendekatan deskriptif eksploratif untuk menggali pendapat stakeholder internal tentang arti penting dan alur model pelayanan unit stroke. Teknik pengumpulan data dengan wawancara tidak terstruktur pada semua komponen yang terlibat dalam pelaksanaan pelayanan di unit stroke. Wawancara dilakukan selama satu minggu dari tanggal 21-25 September 2015 untuk menggali pendapat stakeholder internal mengenai rencana pengembangan unit stroke, alur pelayanannya, sumber daya yang diperlukan, dan hal lain yang terkait dengan pengembangan unit stroke di RS Baptis Batu. Wawancara dilakukan terhadap staf yang terkait dengan pelaksanaan pelayanan di unit stroke, antara lain wakil direktur pelayanan, dokter neurologi, kepala perawat ICU, perawat mahir stroke, kepala perawat IGD, dan dokter rehabilitasi medik RS Baptis Batu. Selama wawancara penulis melakukan pencatatan ringkasan wawancara dan kemudian dituliskan kembali dalam tabel ringkasan wawancara sebagai dasar analisis.

\section{HASIL}

Pendapat Stakeholder Internal tentang Pentingnya Pengembangan Unit Stroke

Tabel 4 menunjukkan hasil wawancara dengan stakeholder internal mengenai pentingnya pengembangan unit stroke di RS Baptis Batu. Wawancara dilakukan dengan para stakeholder yang terkait dengan unit stroke yang bertujuan untuk menyamakan persepsi tentang rencana pengembangan unit stroke. Secara keseluruhan mereka berkomitmen untuk menyetujui dan mendukung adanya pengembangan unit stroke di RS Baptis Batu. Hal ini akan mengkolaborasikan unit-unit pelayanan beserta tenaga medis yang terkait untuk mendukung unit stroke tersebut. Unit stroke ini juga diharapkan dapat menjadi daya ungkit bagi pelayanan di RS Baptis Batu, khususnya rehabilitasi medik. Berdasarkan wawancara tersebut, terdapat beberapa kendala yang dihadapi, antara lain mengenai sumber daya manusia (SDM) berupa perawat mahir stroke yang jumlahnya hanya satu orang serta belum adanya komunikasi lebih lanjut dari tim multidisipliner yang terkait dengan rencana pengembangan unit stroke, khususnya para dokter.

\section{Alur dan Model Pelayanan Unit Stroke}

Berdasarkan wawancara mengenai alur dan model pelayanan di unit stroke, para stakeholder menjelaskan bahwa pasien stroke yang dirawat di unit stroke adalah pasien stroke akut. Alur pelayanan bisa dilihat pada Gambar 1. Hal-hal lain yang terkait dengan unit stroke, seperti indikasi masuk dan keluar pasien ke unit stroke dan discharge planning pasien stroke juga akan dipertimbangkan.

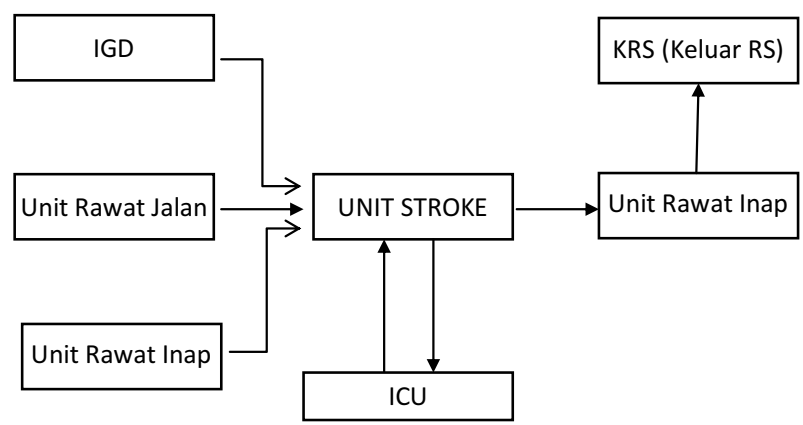

Gambar 1. Alur pelayanan pasien unit stroke RS Baptis Batu

Gambar 1 menjelaskan bahwa pasien yang dirawat di unit stroke dapat berasal dari IGD, ICU, unit rawat inap atau unit

Tabel 4. Rangkuman wawancara pentingnya pengembangan unit stroke

\begin{tabular}{|c|c|c|}
\hline No & Responden & Ringkasan wawancara \\
\hline 1 & Wakil direktur & $\begin{array}{l}\text { Wakil direktur menyatakan setuju dengan rencana pengembangan unit stroke di RS Baptis Batu. } \\
\text { Sumber daya berupa ruangan dan fasilitas yang diperlukan akan segera dipersiapkan. Namun } \\
\text { rumah sakit masih terkendala pada sumber daya manusia berupa perawat mahir stroke yang } \\
\text { hanya berjumlah satu orang. Rencana kedepan, rumah sakit akan mengadakan perekrutan untuk } \\
\text { mengatasi kekurangannya. }\end{array}$ \\
\hline 2 & Dokter neurologi & $\begin{array}{l}\text { Rencana pengembangan unit stroke juga disetujui oleh dokter neurologi. Unit stroke merupakan } \\
\text { unit terpadu yang terdiri dari tim multidipliner yang masing-masing dari mereka sudah } \\
\text { mengetahui tugasnya dalam menangani pasien stroke akut. Harapannya adalah output pasien bisa } \\
\text { menjadi lebih baik. }\end{array}$ \\
\hline 3 & Dokter rehabilitasi medik & $\begin{array}{l}\text { Dokter rehabilitasi medik sangat mendukung jika ada unit stroke di RS Baptis Batu karena akan } \\
\text { bersinergi dengan rehabilitasi medik. Selain itu juga dapat menjadi daya ungkit bagi unit } \\
\text { rehabilitasi medik yang merupakan produk unggulan di RS Baptis Batu. }\end{array}$ \\
\hline 4 & Perawat mahir stroke & $\begin{array}{l}\text { Sebagai satu-satunya perawat mahir stroke di RS Baptis Batu, perawat mahir stroke menyatakan } \\
\text { kesiapannya jika unit stroke ada di RS Baptis Batu. Sumber daya manusia, seperti perawat mahir } \\
\text { stroke harus diperhitungkan sejak awal. }\end{array}$ \\
\hline 5 & Kepala perawat ICU dan IGD & Menyatakan kesiapannya jika unit stroke benar-benar terealisasi di RS Baptis Batu. \\
\hline
\end{tabular}


Tabel 5. Rangkuman wawancara alur dan model pelayanan unit stroke

\begin{tabular}{|c|c|c|}
\hline No & Responden & Ringkasan wawancara \\
\hline 1 & Wakil direktur & $\begin{array}{l}\text { Alur pelayanan dan jenis pelayanan di unit stroke harus dikonsulkan dengan dokter neurologi yang } \\
\text { merupakan penanggung jawab unit stroke. }\end{array}$ \\
\hline 2 & Dokter neurologi & $\begin{array}{l}\text { Hanya pasien stroke akut yang dirawat di unit stroke. Setelah fase akut terlewati, pasien stroke } \\
\text { dipindahkan ke ruang perawatan biasa, namun dengan observasi perawat di ruangan. Misalnya jika } \\
\text { terjadi perburukan, maka pasien tersebut dikirim ke unit stroke atau bahkan ke ICU jika kondisinya } \\
\text { memburuk. Tidak ada formulir khusus tentang indikasi masuk dan keluar pasien stroke. Hanya } \\
\text { ditentukan berdasarkan kondisi pasien. }\end{array}$ \\
\hline 3 & Dokter rehabilitasi medik & $\begin{array}{l}\text { Unit rehabilitasi medik akan memberikan terapi secara dini terhadap pasien stroke, disesuaikan dengan } \\
\text { kondisi pasien dan konsultasi dengan tim dokter yang lain. }\end{array}$ \\
\hline 4 & Perawat mahir stroke & $\begin{array}{l}\text { Hanya pasien stroke akut yang dirawat di unit stroke, namun hal tersebut disesuaikan kembali dengan } \\
\text { kemampuan rumah sakit (fasilitas dan SDM) serta kondisi pasien yang terlebih dahulu dikonsulkan } \\
\text { dengan tim dokter yang merawat. Pasien stroke memerlukan perencanaan pulang khusus untuk pasien } \\
\text { stroke. }\end{array}$ \\
\hline 5 & Kepala perawat ICU & $\begin{array}{l}\text { Perawatan pasien stroke akut seperti perawatan di HCU, setelah pasien stabil, pasien dipindahkan ke } \\
\text { ruang perawatan biasa. }\end{array}$ \\
\hline 6 & Kepala perawat IGD & $\begin{array}{l}\text { Untuk pasien stroke akut yang datang melalui IGD, akan terlebih dahulu dilakukan anamnesa dan } \\
\text { pemeriksaan fisik serta penunjang untuk menentukan diagnosisnya. Setelah dikonsulkan ke dokter } \\
\text { neurologi, selanjutnya pasien stroke akut dikirim ke unit stroke, tergantung kondisi pasien. Tidak ada } \\
\text { formulir khusus tentang indikasi masuk pasien stroke dari IGD, tergantung pada anamnesa dan } \\
\text { pemeriksaan yang dilakukan dokter penanggung jawab pasien yang dikomunikasikan dengan pasien } \\
\text { dan keluarga pasien. }\end{array}$ \\
\hline
\end{tabular}

rawat jalan. Pasien unit stroke adalah pasien stroke dengan stadium akut. Selama perawatan di unit stroke, jika kondisi pasien memburuk maka pasien akan segera dikirim ke ICU untuk mendapatkan perawatan lebih intensif. Jika fase akut pasien stroke telah terlewati, pasien dapat dipindahkan ke ruang perawatan biasa tergantung kelas pasien, dengan monitoring yang baik dari perawat ruangan. Monitoring ini bertujuan untuk menghindari memburuknya kondisi pasien di ruang perawatan biasa.

\section{DISKUSI}

Studi ini menunjukkan kesepahaman stakeholder internal di RS Baptis Batu yang menyepakati tentang pentingnya pengembangan pelayanan stroke komprehensif di rumah sakit, kendala sumberdaya manusia, dan model alur pelayanan yang diharapkan. Pengembangan pelayanan tersebut diharapkan tidak saja dapat meningkatkan pemanfaatan pelayanan unit rehabilitasi medik namun juga meningkatkan kualitas dan harapan hidup pasien.

\section{Pentingnya Unit Stroke di Rumah Sakit}

Hasil studi menyimpulkan seluruh stakeholder internal yaitu manajemen, dokter, dan perawat menyetujui dan mendukung pentingnya pengembangan unit stroke sebagai suatu unit penanganan pasien yang komprehensif. Dukungan diberikan dalam bentuk kesiapan memperkuat sumber daya dan fasilitas, serta kemauan kuat untuk berkolaborasi. Pentingnya pengembangan unit stroke juga dinyatakan dalam Konsensus Nasional Asosiasi Stroke di Amerika Serikat yang berjudul "Stroke The First Hours Emergency Evaluation and Treatment" yang menyimpulkan bahwa stroke membutuhkan pemahaman dan penanganan secara khusus baik oleh tenaga kesehatan maupun masyarakat setempat dalam penatalaksanaannya (). Rumah sakit harus dapat memberikan pelayanan yang cepat, tersedianya unit perawatan khusus stroke dan pelayanan ICU. Perawatan khusus ini di banyak negara diselenggarakan dalam bentuk perawatan terpadu di unit stroke.

Pentingnya pengembangan unit stroke juga didukung fakta kebutuhan pelayanan stroke di Indonesia.
Permasalahan yang mendasari pentingnya unit stroke adalah karena insiden stroke di Indonesia yang tinggi yang cenderung meningkat seiring dengan meningkatnya faktor risiko dan jumlah populasi lanjut usia sebagai akibat bertambahnya umur harapan hidup. Selain itu, stroke juga menyebabkan kematian dan menjadi penyebab kecacatan yang utama. Faktor lain yang berpengaruh adalah gaya hidup seperti pola makan, aktivitas dan stres, merokok, dan lain sebagainya. Dari segi pelayanan kesehatan, pemahaman pimpinan rumah sakit dan para klinisi selain neurologi tentang stroke dan cara penanggulangannya masih perlu ditingkatkan. Selain itu dibutuhkan manajemen penatalaksanaan khusus stroke di rumah sakit. Belum adanya standarisasi pelayanan yang menyeluruh dan terpadu dalam bentuk pelayanan multidisiplin untuk penderita stroke di rumah sakit juga merupakan faktor yang mendasari pentingnya unit stroke di rumah sakit. Kurang menyeluruhnya penyebaran informasi mengenai pedoman penatalaksanaan stroke yang melibatkan pasien, keluarga maupun masyarakat mengenai kedaruratan stroke dan upaya-upaya preventifnya juga merupakan dasar pentingnya unit stroke. Unit stroke juga penting dikembangkan untuk menghadapi tantangan dalam penatalaksanaan stroke akut serta meningkatkan kajian data dasar stroke(8).

Temuan juga menunjukkan pentingnya sinergi dan kerjasama multidisipliner dalam pengembangan unit stroke dengan tujuan meningkatkan mutu luaran pasien. Tujuan perawatan stroke adalah agar penderita stroke pada saat akut dapat terhindar dari kematian, kecacatan yang terjadi diharapkan dapat seminimal mungkin, mengurangi dampak psikologis terhadap keluarga, penderita dan masyarakat serta jika dapat semua itu dicapai dengan biaya serendah mungkin (9). Hal itu dapat diwujudkan melalui penanganan penderita stroke akut secara multidisipliner terpadu dan diteruskan sampai penderita pulang (10). Cara perawatan ini merupakan modal perawatan yang lebih terorganisasi dan secara teknis mengintegrasikan seluruh disiplin yang terkait dengan perawatan stroke akut. Kombinasi perawatan akut dan rehabilitasi dini merupakan faktor penting untuk 
perawatan unit stroke yang efektif $(11,12)$. Pendekatan terapi stroke harus komprehensif, meliputi terapi hiperakut onset kurang dari 6 jam, akut, rehabilitasi dan prevensi sekunder. Rencana perawatan sejak masuk sampai pulang disusun bersama-sama oleh tim multidisiplin yang dipimpin seorang dokter spesialis penyakit saraf(13). Dengan cara ini akan terjadi kerjasama multidisipliner yang terpadu dan terarah untuk kepentingan pasien stroke dan keluarganya(14).

Disamping perlunya kerjasama multidisiplin, stakeholder juga mengharapkan dampak pengembangan pelayanan pada luaran pasien. Unit stroke telah terbukti efektif dalam menekan angka kematian, menurunkan derajat kecacatan, ketergantungan jangka panjang, mengurangi waktu perawatan dan biaya perawatan bagi pasien di rumah sakit $(12,15-18)$. Hasil penelitian yang dilakukan di RS Ciptomangunkusumo didapatkan rata-rata lama perawatan lebih rendah pada unit stroke $(9,7$ hari) dibandingkan bangsal biasa (10,1 hari). Oleh karena itu dana yang diperlukan untuk perawatan, pengobatan dan rehabilitasi pasien stroke dapat ditekan sekecil mungkin (19). Hal itulah yang menjadi dasar perlu dikembangkannya unit stroke di RS Baptis Batu.

\section{Model dan Alur Pelayanan di Unit Stroke}

Salah satu hal yang perlu disepakati dalam pengembangan unit stroke pada studi ini adalah kejelasan alur dan tanggungjawab. Aturan dan tanggung jawab semua pelaksana di unit stroke harus jelas dan perawatan pasien harus terstandarisasi. Protokol tersebut harus disepakati sebagai suatu standarisasi perawatan intensif stroke berdasarkan guidelines manajemen stroke yang terkini(9). Alur manajemen terhadap pasien stroke akut mungkin untuk setiap pasien tidak sama, dan hal itu tergantung dari kedatangan pasien ke rumah sakit. Beberapa kondisi dan komplikasi pada pasien stroke akut misalnya krisis hipertensi, peningkatan kadar gula darah, aspirasi, peningkatan tekanan intrakranial, bangkitan kejang, atau aritmia jantung harus selalu dimonitor dan dievaluasi dalam manajemen stroke akut dan masuk dalam clinical pathway manajemen stroke (12). Kondisi pasien stroke akut yang harus dimonitor antara lain: observasi terhadap kondisi kardiovaskuler maupun neurologis, mencegah timbulnya komplikasi serta mendeteksi secara cepat dan tepat untuk melakukan tindakan medik maupun intervensi pembedahan. Manajemen stroke bertujuan untuk memantau sistem respirasi dan kardial, pemberian cairan dan manajemen terhadap gangguan metabolik, pengendalian tekanan darah, pencegahan terhadap deep venous thrombosis dan emboli pulmonum, pencegahan terhadap aspirasi pneumonia dan infeksi lainnya dan pencegahan dekubitus(9).

Temuan menyimpulkan pelayanan stroke harus komprehensif dan bersifat multilevel. Pelayanannya dimulai dari prahospital, pasien ditangani di IGD, pelayanan pasien di unit stroke hingga pasien pulang. Unit stroke merupakan perawatan high care, bukan intensive care. Unit stroke berkedudukan diantara ICU dan bangsal perawatan neurologi. Pelayanan High Care Unit (HCU) adalah unit pelayanan di rumah sakit bagi pasien dengan kondisi stabil dari fungsi respirasi, hemodinamik, dan

\section{DAFTAR PUSTAKA}

1. Young J and Forster A. Rehabilitation after Stroke. British Medical Journal. 2007; 334(7584): 86-90.

2. Laksana E, Hariyanto $T$, dan Pusparahaju A. kesadaran namun masih memerlukan pengobatan, perawatan dan pemantauan secara ketat (20). Kekuatan utama perawatan stroke di unit stroke adalah observasi status neurologi dan keadaan umum secara ketat. Komponen utama perawatan di unit stroke adalah penyelamatan jiwa (1-4 minggu setelah stroke) dan menurunkan ketergantungan yang bertujuan untuk perawatan yang lebih efektif.

Rehabilitasi medik merupakan bagian penting dalam pelayanan stroke. Unit stroke merupakan unit yang dikhususkan untuk pasien stroke yang merupakan kombinasi dari perawatan akut dan upaya rehabilitasi dini sebagai faktor penting yang efektif dalam unit stroke (11). Program rehabilitasi adalah bentuk pelayanan kesehatan yang terpadu dengan pendekatan medik, psikososial, educational, vocational yang bertujuan mencapai kemampuan fungsional semaksimal mungkin dan mencegah serangan berulang. Mobilisasi merupakan salah satu bentuk rehabilitasi awal pada pasien yang mengalami serangan stroke sehingga dapat terhindar dari komplikasi (21). Pasien dengan stroke harus dimobilisasi dan dilakukan fisioterapi sedini mungkin jika kondisi neurologis dan hemodinamik stabil. Fisioterapi pasif pada pasien stroke belum diperbolehkan. Latihan gerakan sendi anggota badan secara pasif empat kali sehari untuk mencegah kontraktur. Faktor yang paling penting dalam rehabilitasi adalah kontinuitas perawatan, oleh sebab itu pasien post stroke penting melakukan rehabilitasi. Untuk menjamin keberlanjutan pelayanan, petugas perlu meningkatkan motivasi pasien untuk mencegah komplikasi dengan cara menekankan latihan serta menjelaskan bahwa pemulihan terjadi secara bertahap sehingga perlu ketekunan dalam latihan dan perlunya meningkatkan partisipasi keluarga dalam membantu pelaksanaan mobilisasi dini (22).

Salah satu faktor penting untuk menjamin keberlanjutan pelayanan stroke adalah peran perawat dalam membuat discharge planning (perencanaan pulang pasien) (23). Perencanaan pulang adalah suatu proses yang sistematis untuk menilai, menyiapkan, dan melakukan koordinasi dengan fasilitas kesehatan yang ada atau yang telah ditentukan serta bekerjasama dengan pelayanan sosial yang ada di komunitas, sebelum dan sesudah pasien pindah atau pulang. Discharge planning ini penting untuk mempertahankan kontinuitas perawatan. Kegiatan discharge planning dilakukan berdasarkan formulir discharge planning yang sudah ada di rumah sakit. Namun di rumah sakit jarang terdapat lembar khusus discharge planning untuk pasien stroke(23).

Unit stroke merupakan unit komprehensif, yang merupakan kombinasi dari perawatan stroke akut serta rehabilitasi dini. Pengembangan unit stroke memerlukan perencanaan yang baik yang harus dianalisis dari berbagai aspek. Rumah sakit Baptis Batu dalam pengembangan unit stroke perlu melakukan studi kelayakan untuk mengakaji aspek organisasi dan manajemen, fasilitas yang dibutuhkan, standar operasional prosedur (SOP), jumlah SDM (perawat mahir stroke dan tim multidisipliner) yang dibutuhkan berdasarkan kompetensi di unit stroke, dan pembiayaan.

Positioning Unit Rehabilitasi Medik Sebagai Centre of Excellence di Rumah Sakit Baptis Batu. Jurnal Kedokteran Brawjaya. 2014; 28(1): 26-30.

3. Lloyd-Jones D, Adams RJ, Brown TM, et al. Heart 
Disease and Stroke Statistics-2010 Update: A Report from the American Heart Association. Circulation. 2010; 121(7): e46-e215.

4. Kementrian Kesehatan Republik Indonesia. Riset Kesehatan Dasar. Jakarta: Badan Penelitian dan Pengembangan Kesehatan Kementrian Kesehatan RI; 2013.

5. Sorganvi V, Kulkarni MS, Kadeli D, and Atharga S. Risk Factors for Stroke: A Case Control Study. International Journal of Current Research and Review. 2014; 6(3): 46-52.

6. Laloux P, Lemonnier F, and Jamart J. Risk Factors and Treatment of Stroke at the Time of Recurrence. Acta Neurologica Belgica. 2010; 110(4): 299-302.

7. Meschia JF, Bushnell C, Albala BB, et al. Guidelines for the Primary Prevention of Stroke. Stroke. 2011; 42: 517-584.

8. Arisetijono E. Peran Stroke Unit dalam Penanganan Komprehensif Penderita Stroke. (Online) 2004. http://www.scribd.com/doc/38698349/PeranStroke-Unit-Dalam-Penanganan-KomprehensifPenderitaStroke\# scribd.

9. Perdossi. Guideline Stroke Tahun 2011. Jakarta: Perdossi; 2011.

10. Clarke DJ. The Role of Multidisciplinary Team Care in Stroke Rehabilitation. Progress in Neurology and Psychiatry. 2013; 17(4): 5-8.

11. Langhorne P, Pollock A, and Stroke Unit Trialists' Collaboration. What are the the Components of Effective Stroke Unit Care? Age and Ageing. 2002; 1(5): 365-371.

12. Stroke Unit Trialists Collaboration. Organized Inpatient (Stroke Unit) Care for Stroke. The Cochrane Database of Systematic Reviews. 2007; (4): Cd000197.

13. Mulyani S dan Besral. Ketahanan Hidup Setahun Pasien Stroke di RS Cipto Mangunkusumo Jakarta. Jurnal Kesehatan Masyarakat Nasional. 2007; 2(3): 120-126.
14. Hanna H. Analisis Faktor-faktor Pelayanan yang Mempengaruhi Bed Occupancy Rate (BOR) Unit Stroke Center Rumah Sakit Islam Jakarta (Tahun 2000-2003). Universitas Indonesia, Jakarta. 2004.

15. Seenan $\mathrm{P}$, Long $\mathrm{M}$, and Langhorne P. Stroke Units in their Natural Habitat: Systematic Review of Observational Studies. Stroke. 2007; 38(6): 18861892.

16. Zhu H, Newcommon NN, Cooper ME, et al. Impact of a Stroke Unit on Length of Hospital Stay and InHospital Case Fatality. Stroke. 2009; 40(1): 18-23.

17. Rocha MSG, Almeida ACF, Neto OA, Porto MPR, and Brucki SMD. Impact of Stroke Unit in a Public Hospital on Length of Hospitalization and Rate of Early Mortality of Ischemic Stroke Patients. Arquivos De Neuro-Psiquiatria. 2013; 71(10): 774-779.

18. Schouten LMT, Hulscher MEJL, Akkermans R, Everdingen JJE, Grol RPTM, and Huijsman R. Factors that Influence the Stroke Care Team's Effectiveness in Reducing the Length of Hospital Stay. Stroke. 2008; 39: 2515-2521.

19. Rasyid A, Saleh M, dan Misbach J. Stroke Unit: Does It Make a Difference? Assesment of the Early Effectiveness of a Stroke Unit in Improving Functional State in Dr. Cipto Mangunkusumo Hospital. Medical Journal Indonesia. 2006; 15(1): 30-33.

20. Departemen Kesehatan Republik Indonesia. Keputusan Menteri Kesehatan No. 834/Menkes/SK/II/2010 tentang Pedoman Penyelenggaraan Pelayanan High Care Unit (HCU) di Rumah Sakit. Jakarta: Kementrian Kesehatan RI; 2010.

21. Purwanti OS dan Maliya A. Rehabilitasi Klien Pasca Stroke. Berita Ilmu Keperawatan. 2008; 1(1): 43-46.

22. Wirawan RP. Rehabilitasi Stroke pada Pelayanan Kesehatan Primer. Majalah Kedokteran Indonesia. 2009; 59(2): 61-71.

23. Hariyati TS, Afifah E, dan Handiyani H. Evaluasi Model Perencanaan Pulang yang Berbasis Teknologi Informasi. Makara Kesehatan. 2008; 12(2): 53-58. 